\title{
Subepithelial Collagen Band Present
}

National Cancer Institute

\section{Source}

National Cancer Institute. Subepithelial Collagen Band Present. NCI Thesaurus. Code

C96216.

A morphologic finding indicating the presence of a collagen band under the epithelial layer in a tissue sample. 